\title{
Impact of Interactive Pedagogies on Students' Academic Achievement in Mathematics at Elementary School Level in Quetta City, Balochistan.
}

\author{
Dr. Alia Ayub, Assoc. Prof. Education dept, SBKWU. Quetta, aliaaslam54@yahoo.com \\ *Dr. Rani Gul, Assistant Professor, Department of Education, University of Malakand, KPK, Pakistan, \\ dr.rani27@gmail.com \\ Dr Misbah Malik, Assistant Professor, Institute of Education and Research, University of Punjab, Lahore, \\ Pakistan \\ Prof. Dr. Muhammad Yousuf Sharjeel, Department of Education, SZABIST, Karachi, Pakistan \\ Dr. Maroof Bin Rauf, Assistant Professor Dept. of Education, University of Karachi, Pakistan
}

\begin{abstract}
This proposed research tested the impact of interactive pedagogies (demonstration and discussion pedagogies) on students' academic achievement in Mathematics at elementary school level. This study was limited to Quetta city of Baluchistan, Pakistan. This study was emphasized, to analyse the current pedagogies in use at elementary Mathematics' classrooms, to highlight the difficulties which students are facing in understanding the Mathematics, to explore the impact of interactive pedagogies on students' academic achievement in Mathematics and to find out the strategies for implementing the interactive pedagogies in an effective way. The sample size was the 235. (N\#235). 200 students (grade 11 \& 12), 30 teachers (mathematics teachers) and 5 experts were the sample of this research study. This study used mixed method in design. Both quantitative and qualitative data was collected. The quantitative data was collected through observation checklist, pre-test, and post-test while qualitative data was collected through interview. The quantitative data collected through observation was analysed through frequency and \%ages while pre-test, post-test was analysed through paired sample t-test by entering the data into SPSS 20 version. Qualitative data collected was analysed through thematic analysis.
\end{abstract}

Keywords: Interactive, Academic, Elementary, Students

Received: 07.12.2020 $\quad$ Accepted: 13.01.2021 $\quad$ Published: 06.02.2021

\section{INTRODUCTION}

The most vigorous subject in our daily life is Mathematics. It has an influence on almost all branches of social and natural sciences. Without studying mathematics, the cultural and intellectual level development is not possible (Yasoda, 2009). Moreover, it helps to develop abilities, like critical thinking, analytical reasoning, and conceptual understanding of the complex natural problems (Gul, R., Khan, S. S., Mazhar, S., \& Tahir, T. (2020). It makes the learners good citizens. It has a vital role in shaping how individuals from different fields' private and civil life deal with their challenges (Anthony \& Walshaw, 2009). Imagine a world without mathematics, we would not be able to count or do any other work related to this subject. It influences, self-esteem, social, economic, moral, and technological development (Gul, R., Kanwal, S., \& Khan, S. S., 2020).

The world around us is changing rapidly. Global education trends are influencing the policies of the developing countries. Mathematics must sustain its existence for development of the country. It is therefore valued at the time of the policy-making process. The course curriculum should be designed with modern approach meeting with the challenges of the $21^{\text {st }}$ century education trends (Gul, R., Khan, S. S., \& Akhtar, S., 2020), there has been an increase in research on mathematics education. Mathematics has complex abstract concepts, complicated calculations, unique terminology makes it difficult for the learners to tackle this subject. Some students face difficulties due to teaching methods (Gul, R., \& Rafique, M., 2017).

According to Gul, R., \& Reba, A. (2017), pupils must enhance their learning skills and knowledge. They need to face and survive in the global education scenario. The teaching methods should be transformed from traditional mode to new pedagogies, in order to sustain the learner's abilities. The National Research Council (2012) found that better teaching methods can make the pupils develop critical thinking abilities. The highly competitive and active pedagogical instructors should provide solid results in achieving equal education around the globe. (UNESCO-IBE, 2013). 


\section{Objectives of the Study}

The proposed study aimed:

- To analyse the current pedagogies in use in elementary school Mathematics' classrooms.

- To highlight the difficulties faced by the students in mathematics classrooms.

- To explore the impact of interactive pedagogies on students' academic achievement in Mathematics.

- To find out the strategies for implementing the interactive pedagogies in an effective way.

\section{Research Questions}

1. What are the current pedagogies in use?

2. What difficulties are faced by the students in mathematics classrooms?

3. What is the impact of demonstration and discussion pedagogies on the students' academic achievements?

4. How these pedagogies can be implemented in an effective way?

\section{LITERATURE REVIEW}

\section{Importance of Mathematics}

Mathematics is admired to be a core subject for educational settings and problem-solving, it develops cognitive domain of the pupils. The curriculum and teachers' pedagogical knowledge about mathematics can produce good results. It seems hard to develop teaching methods for maths, but in modern world we can utilize different technological and pedagogical ways to improve the learning process (Gul, R., et al. 2020). It influences every aspect of life from arts, social sciences, natural sciences, and personal development. B.S Bloom developed learning strategies for improving the learning methods. His methods were great in polishing students' skills in learning mathematics. With the better pedagogical knowledge, we can create a learning-friendly environment and end math phobia. The instructor can develop different strategies for building conceptual and better understanding of mathematical abstract concepts (Laski, E. et al., 2015). Gul, R., et al. (2020) found that students and teachers consider mathematics, a vital subject. Although having a hard time to understand and learn mathematics they consider it to be a true subject, they said, it has never been proven wrong. The first thing that student ask their teacher is about mathematics uses. Why do they need to study maths? Why they are forced to learn, complex calculation techniques. What role does mathematics have in daily life and real -world problems? These types of questions are hard to be answered by their instructor. The mentor tries to find best possible methods to teach them mathematics effectively (Gul, R., 2015). Student learns mathematical concepts better. If they are exposed to different aids and teaching strategies (Piaget, 1965).

Moreover, methods and materials may not be a complete solution to math-phobia. These approaches help in creating an environment that will be helpful for a common perception between mentors and their pupils, such types of pedagogical approaches will build the cognitive domain of the student. They should learn hard mathematical concepts without any difficulty (Cope, 2015).

\section{Importance of Teaching Methods}

Yilmaz et al. (2010), identified that teacher's face immense pressure due to National and International trends also affect their teaching approaches and results. Warwick (2008) in a study observed that teaching methodologies have a strong influence on students' learning process and self-efficacy. The findings of the research (Gul, R., et al. 2020; Gul, R., 2015) showed that teaching methods influence the cognitive domain of the learner. The teaching methods either make the pupils dull or they develop effective critical thinking abilities. The United Kingdom as set pedagogical knowledge and pedagogical teaching methods as their topmost priority.

\section{Student-Teacher Interaction}

Another perspective is the student-teacher relationship/interaction, which shows how a teacher approaches guide the transferring of the knowledge. The available literature on this show that teacher can bring out the best in learners. The modern teaching strategies have a great positive impact on learners and boost their learning abilities (Mensah et al., 2013). The research work done during the last decade has shown that different teaching pedagogies have produced effective results. Especially in mathematics achievements, the interactive pedagogies have proven to be effective. The researchers say pedagogical teaching methods are the main part in teaching mathematics, as found by (Yara, 2009). The 
positive attitude and best teaching strategies of the tutor bring the best in pupils, their concept grows stronger.

\section{Blended Pedagogy}

In another study conducted by (Erkishava et al., 2014), the researchers discussed a blended pedagogy. The ethno-pedagogy is an approach where traditional teaching approach is blended with the Nations connection to its foundations with the help of modern teaching strategies. This strategy was effective in teaching mathematics. This research shows how we can achieve positive output from interactive teaching methods. We can realize pedagogy as an art, and the teacher as an artist. The teacher with best available resources and environment shapes his learners' mind into critical thinking (Bhowmick et al., 2013), Although there is no permanent single method that can be considered effective teaching of mathematics. Therefore, the teacher's pedagogical knowledge and approach make the difference.

Furthermore, teaching mathematics is very important. It influences how the student will perform in their future. Mathematics affects all dimensions of life, on individual and collective levels (Anthony \& Walshaw, 2009). This shows why we need to have some of the best approaches for teaching mathematics. Studies show that failure in mathematics discourages the pupils from studying it. Especially the student of pre-engineering, computing and health professions need to excel at mathematics. These fields involve calculations and mere calculation mistakes can be quite crucial (Glaister, 2007). Most pupils fail to get good marks in mathematics, or they drop this subject. The reason behind this is, they consider it as a boring and hard subject to excel (Keefe, 1997).

\section{Role of Teacher in Teaching - Learning Process}

Teachers act as a catalyst in the learning process. They can change student attitude towards learning mathematics. A teacher should act as a guide during the lecture time in the classroom. The mentor should approach the student with such strategies, that they take more interest during the class session. Different pedagogical approaches with modern technological instruments should provide a deeper understanding of math problems and complex concepts. Mathematics teaching and learning becomes very interesting when the teaching methods are interacted with hybrid teaching technology (Khairnar, 2015).

Moreover, the world is changing into a global village. The education policies of the nation are not free; they are affected by the global education policy trends. The curriculum and teaching methods should meet the global educational trends (Cullen, J. 2013). The developing countries like Pakistan lack in the teaching pedagogies. Mostly they are using traditional teaching approach. They are not familiar with the modern teaching strategies or they avoid interacting with their pupils using these modern pedagogies and technology in their teaching methods (Holmes, 2013).

\section{Peer - Teaching}

(AbdelKarim \& Abuiyada, 2016), in their work shows the benefits of peer-teaching on learners. They showed the pedagogies can improve the pupils' perception towards learning. The work showed peerteaching as an active tool for improvising the learning abilities of the student. The study conducted by Brufee K.A. (1999) shows, if student interacts with the technology, they can improvise their knowledge and learning capabilities. Using modern instruments with interactive pedagogies can be vital in learning process towards understanding abstract and complex problems of math.

\section{Interactive Pedagogies}

The teaching methods where student interacts with different tools, different fellow groups and with their mentor, these methods are known as interactive pedagogies, interactive pedagogies are proven to be quite effective as compared to the traditional or other old teaching methods (Scott, 2015). It helps student to develop critical thinking skills, analytical abilities are boosted with interaction to the available education instruments. In the modern era students are active learners, they argue and try to give their views about the problem (Lead B., 2010). Students' capabilities are enhanced when they are given problems and project-based learning. The pupils learn to build their knowledge by designing and constructing a solution to real world problem form daily life (Cornell University, 2014a).

\section{Role of Interactive Pedagogies}

According to (Beetham \& Sharpe, 2013), the 21 $1^{\text {st }}$-century learning technologies have a great influence on knowledge sharing. Knowledge is subject to rapid change; the interactive pedagogies help in filling this gap. These methods help to develop better inquiry, dialogue between mentor and pupils. Cerghit, I. (2006) also emphasized on the interactive approaches of teaching, for surviving in this changing world of 
education. The learners will develop curiosity and ask challenging questions to their mentor, if they are exposed to interactive pedagogies of teaching, they will also develop a sense of finding answers to such challenging questions.

(Sessoms, 2008) discussed that Interactive pedagogies are proving to be result oriented, these methods are following constructivism. These pedagogies provide quite effective results when used with interactive tools, such as interactive whiteboard and web 2.0. Such instruments aim to develop a stronger perspective of the student towards mathematics. Interactive whiteboard when used in schools of England, the pupil knowledge and concepts were improved. Such teaching methods help the learner to think out of the box and develop problem-solving techniques (Glover, 2003). The teacher is like an actor who adopts and performs the assigned work, the mentor attracts the student to take interest in classroom conversation and lecture (Bocos, 2002)

\section{RESEARCH METHODOLOGY}

This study aims to find out the impact of interactive (discussion and demonstration) pedagogies on students' achievement in mathematics, at elementary school level in Quetta city of Balochistan Province.

\section{Research Design}

The research paradigm for this proposed study was mixed method approach. The combination of qualitative and quantitative methods helps us in the collection of the more reliable and vital data. The mixed method approach was chosen so that both qualitative (interview) and quantitative (observations, pre-test, post-test) approaches contribute to the investigation of research questions.

\section{Population of the Study}

The population was comprised of all the male and female students, enrolled in the elementary school level in public sector colleges. The Subject specialist and teachers were also providing their point of views about pedagogical knowledge.

\section{Sample and Sampling Technique of the study}

03 male and 03 female public sector schools were selected through convenient sampling technique and then 100 male and 100 female students enrolled in $7^{\text {th }}$ and $8^{\text {th }}$ grades were selected through purposive sampling technique.

Teachers and expert were selected through purposive sampling technique. 200 students, 30 teachers and 5 experts were the sample of this research study. Thus, a total of 235 participants participated in the study.

\section{Research Tools}

Data was collected through developing the following research tools:

- Observation checklist: It assisted in answering the research question, what are the current pedagogies in use?

- Pre-test: The quantitative data of the proposed research was based upon pre-test post-test. A pretest was taken before using the discussion and demonstration methods in mathematics classrooms.

- Post-test: A post-test answer the $2^{\text {nd }}$ research question, to evaluate the impact of discussion and demonstration methods on learners. Students were taught different topics in mathematics, cover about $40 \%$ of the course in one month ( 40 classes/school)

- Interview Protocol. Interview was taken from the teachers engaged in teaching of mathematics to elementary school students and with the experts of Mathematics. This interview with the teachers and experts was conducted to find out difficulties, students faced in learning mathematics and the ways for effective implementations of interactive pedagogies in Mathematics classrooms. Interviews supports to answer the research question $3^{\text {rd }}$ and $4^{\text {th }}$.

\section{RESULTS}

\section{Analysis of observation data}

The quantitative data collected through observation checklist was analysed through descriptive analysis frequencies and percentages. 24 observations of mathematics classrooms were made, 4 observation in each of the sample school. Results are presented as under 
Table 1.

\begin{tabular}{|l|l|l|}
\hline Observations & Frequency & Percentages \\
\hline Teachers engage the students in solving the different questions. & 14 & $58 \%$ \\
\hline $\begin{array}{l}\text { Teachers engage the students in discussing the different concepts } \\
\text { of mathematics. }\end{array}$ & 0 & $0 \%$ \\
\hline $\begin{array}{l}\text { Teachers demonstrate some difficult concepts through some } \\
\text { Practical. }\end{array}$ & 0 & $0 \%$ \\
\hline Teacher use audio visual aids to clarify some concepts. & 6 & $25 \%$ \\
\hline Teachers ask the questions about teaching content. & 10 & $42 \%$ \\
\hline $\begin{array}{l}\text { Teachers allow the students to ask questions about the concepts, } \\
\text { they don't understand. }\end{array}$ & 16 & $25 \%$ \\
\hline $\begin{array}{l}\text { Teachers give the examples from daily routine life to show the } \\
\text { practicality of the Mathematics }\end{array}$ & 6 & $0 \%$ \\
\hline Teachers assign the tasks to the students to do in a group. & 0 & $0 \%$ \\
\hline $\begin{array}{l}\text { Teachers give the projects to the students for solving different } \\
\text { Mathematical problems }\end{array}$ & 0 & $0 \%$ \\
\hline $\begin{array}{l}\text { Teachers show the videos to relate the mathematical calculations } \\
\text { to a practical implication. }\end{array}$ & 0 & \\
\hline
\end{tabular}

\section{Analysis of pre-test and post-test}

Pre-test and post-test was analysed through paired sample t-test by entering the data into SPSS 20 version. Results are tabulated as under:

Table 2.

\begin{tabular}{|l|l|l|l|l|l|}
\hline \multicolumn{2}{|l|}{ Paired Samples Statistics } \\
\multicolumn{2}{|l|}{} & Mean & N & Std. Deviation & $\begin{array}{l}\text { Std. } \\
\text { Mean }\end{array}$ \\
\hline \multirow{2}{*}{ Pair 1 } & pretest & 49.3200 & 200 & 15.52491 & 1.09778 \\
\cline { 2 - 7 } & posttest & 77.4500 & 200 & 11.06616 & .78250 \\
\hline
\end{tabular}

The table 2 indicates that highest mean $(\mathrm{M}=77.45)$ in the mathematics achievement scores in post-test than the mathematics achievement scores in pre-test $(M=49.32)$

Table 3.

\begin{tabular}{|l|l|l|l|l|l|l|}
\hline \multicolumn{2}{|l|}{ Paired Samples t-test } & & & \\
\multicolumn{2}{|l|}{} & Paired Differences & \multicolumn{2}{l|}{} \\
\cline { 3 - 4 } & Mean & Std. Deviation & $\mathrm{t}$ & $\mathrm{df}$ & Sig. (2-tailed) \\
\hline Pair 1 & pretest - posttest & -28.13000 & 12.04402 & -33.030 & 199 & .000 \\
\hline
\end{tabular}

The table 3 indicates the significant difference level between the mathematics' achievement scores between pre-test and post-test scores. $\{\mathrm{t}(199)=-33.030, \mathrm{p}=.000\}$

This table also indicates significant mean difference $(M=-28.13000)$

\section{Analysis of interview data}

Qualitative data collected through interview was analysed through thematic analysis.

Following themes were identified:

\section{Difficulties faced by the students}

- Problem in differentiating the formulas

Teachers responded that majority of the students feel difficulty in remembering the formulas. Some of the teachers said "students often make mistakes by putting wrong formulas, which resulted in less scores in their exams" some other teachers responded that "sometimes formulas differed with minor changes, so students make a lot of mistakes in differentiating these formulas"

- Difficulty in derivations of functions

About all the teachers responded that "students feel get confused in the derivations of the functions". Majority of the teachers responded that the very little no. of students derived the functions accurately.

- Students feel bored in theorems' classes 
Majority of the students didn't take interest in solving the theorems. Some teachers responded that "students show boring attitudes in solving the theorems"

- Difficulty in drawing the geometrical figures

Some of the teachers responded that "students also feel difficulty in drawing the different geometrical figures as most of the figures have almost same shapes".

\section{- Problem in identifying the different equations}

Majority of the respondents said "students feel lot of difficulty in generating the equations as they are dealing with calculating the variables and emphasizing the right order at the same time". Students feel it a hectic task.

- Solving word problems

Teachers also highlight that the students also felt difficulty in analysing and choosing the correct operations in solving the word problems

\section{Suggestions by the experts}

- Focused on making strong base of mathematics

Experts viewed that Mathematics operations are difficult as compared to other subjects. So they suggest that "students should be given extra intentions on clarifying the basic concepts of mathematics. After that they should be teach the difficult concepts".

- Make students, experts in algebraic knowledge

According to experts, algebraic procedures are used in the solutions of many problems, equations, functions and derivations, so they suggest "students should be made expert in this area at their elementary level".

- Provide trainings to the teachers

They also suggest that "the teachers involved in the teaching of mathematics should be provide trainings on continuous basis in order to improve and up to date their knowledge".

- Engage the students in practice

Experts considered practice as a good tool for clarifying and commanding the knowledge they suggest "students should be given the lot of assignments to solve the problems. Assignments should be focused on the concepts, which students feel difficult to understand".

\section{DISCUSSION}

The observation data revealed that the traditional teaching methods are practiced in the mathematical classrooms, mathematics is a difficult subject so different teaching styles should be used to clarify the mathematics' concepts.

When students were taught through discussion and demonstration methods, the results showed improvement in scores on mathematics' achievement test, after these interventions.

The results of this research study illustrate that the students were facing difficulties in all areas of mathematical concepts. Major difficulty was in solving word problems, derivations and generating the equations.

Experts suggest training of mathematics teachers' engaging students in practicing the difficult solutions. They also emphasized on making the strong base of the students at elementary levels, so that the students can learn the difficult concepts at elementary school level.

\section{CONCLUSION}

From the results of the study, it is concluded that the students are facing a lot of difficulties in learning mathematics. Because of these difficulties they hate this subject and even drop out the learning. When students were teach through discussion and demonstration method they enjoy the mathematics classrooms. So they should be teach mathematics by applying the interactive pedagogies and engaging the students in different assignments, and group tasks, so that they can clarify and understand the concepts on time.

\section{RECOMMENDATIONS}

\section{Engage students in classroom discussions}

Mathematics is a difficult subject, majority of the student loose interest in understanding the difficult concepts. If students are engaged in discussion during teaching - learning process, their misunderstandings can be clarify on the spot. 


\section{Engage students in group discussions}

Sometimes students better learn from their peers, so after teaching mathematics' content engage the students in solving the problems. For this purpose make group of 5-6 students. Each group comprises of intelligent, average and below average students.

\section{Use A.V. aids to clarify different concepts}

Mathematical concepts appear an abstract thing to the students, some concepts need to observations for clarifications. So it is suggested, use audio-visual aids in teaching of difficult concepts.

\section{Relate the Mathematical concepts with its implications}

Students don't, feel the value of mathematics except subtraction, addition, multiplications and divisions. The syllabus of intermediate includes derivations, equations, complex numbers solutions, functions etc. so it is necessary to relate these concepts with their practical implications in daily routine life.

\section{Revise basic concepts of Algebra in 1-2 classes}

The little interest of the students towards is because of their weak mathematical base. As intermediate classes with mathematics are known as pre-engineering classes. So all the concepts must be clearly understood by the students so that they can continue their future learning as engineers. So it is the duty of the teachers that in the start of the session, 1-2 classes should be focused on clarifying the basic concepts of mathematical operations

\section{Train the teachers with specific teaching pedagogies}

Mathematics is very important subjects but it is taught through solving some of the problems on whiteboard. That's why students get bored in learning the mathematics. So there is greater need to teach the mathematics by using interactive teaching methods. As teachers in colleges are just trained in teaching of the content, they should be provide specific training on the teaching mathematics' pedagogies.

\section{Word problems need to more considerations}

Students feel difficulty in identifying the operations hidden in the words of the problems. So teachers should engage the students in practices of word problems. They should be given the tricks how they can identify the operations in word problems.

\section{REFERENCES}

Abdelkarim, R, \& Abuiyada, R., (2016). The effect of Peer Teaching on mathematics academic achievement of the undergraduate Students in Oman. International Education Studies. Vol. 9, No. 5; 2016. ISSN 1913-9020 E-ISSN 1913-9039.

Akhter, N. Akhtar, M. \& Abaidullah, M., (2015). The perception of high school mathematics problem solving Teaching methods in mathematics education.Bulletin of education and research. Vol. 37, No. 1 pp. 1-23.

Amirali, M., (2010). Students' conceptions of the nature of mathematics and attitudes towards mathematics learning. Journal of research and reflections in education. Vol. 4, No. 1, pp 27-41.

Amirali, M. \& Halai, A., (2010). Teachers' Knowledge about the nature of Mathematics: A survey of Secondary School Teachers in Karachi, Pakistan. Bulletin of Education and Research. Vol, 32, No. 2 pp. 45-61.

Anthony, G., \& Walshaw, M. (2009). Characteristics of effective teaching of Mathematics; A view from the west. Journal of Mathematics Education. 2(2), 147- 164.

Beetham, H., \& Sharpe, R., (eds), (2013). Rethinking Pedagogy for a digital age. $2^{\text {nd }}$ edn. New York, Routledge.

Bhowmik, M. Roy, B. B \& Banerjee, j., (2013). Role of pedagogy in effective teaching. Basic research Journal of education research and review. ISSN 2315-6872. Vol. 2(1) pp. 01-05.

Bocoș, M. (2002). Interactive instruction. Highlights for Reflection and Action. Cluj: University Press Publishing House.

Brufee, K.A. (1999). Collaborative learning. Higher education interdependence, and the Authority of Knowledge (paperback). Bailtimore MD: Johns Hopkins University Press.

Cope, L. (Spring 2015). Math manipulatives; Making the abstract tangible. Delta journal of Educaton, 5(1), 10-19. 
Cerghit, I., (2006). Education method. Fourth edition- revised and added. lasi: Politom. Publishing house.

Cornell University Center for Teaching Excellence. (2014a). Problem-based learning.

Cullen, J., (2013). Our schools are stuck-the gap between educational policy and reality why schools are stuck and need to change. MENON Network Policy Brief, No. 3, pp. 1-9.

Erkisheva, Z. Koshanova, M. Alikhanova, B. Omarova, I. Baitenov, A. \& Abishova, A. (2014). Using the elements of Ethno Pedagogies in Teaching Maths. Procedia- Social and Behavioral Sciences. 143, 591-594.

Fatima, R. (2012). Role of Mathematics in the Development of Society. National Meet on Celebration of National year of Mathematics-2012; organized by NCERT, New Delhi, December 20 - 22.

Glover, D; Miller, D. \& Averis, D., (2003). The impact of interactive whiteboards on classroom practice: examples drawn from the teaching of mathematics in secondary schools in England. The mathematics educaton into $21^{\text {st }}$ Century Project. Proceedings of the international conference. The Decidable and Undecidable in mathematics education. Brno, Czech Republic.

Glaister, K. (2007). The presence of mathematics and computer anxiety in nursing students and their effects on medication dosage calculations. Nursing education today. 27(4): 341-347.

Gul, R., Khan, S. S., Mazhar, S., \& Tahir, T. (2020). Influence of Logical and Spatial Intelligence on Teaching Pedagogies of Secondary School Teachers. Humanities \& Social Sciences Reviews, 8(6), 01-09. https://doi.org/10.18510/hssr.2020.861

Gul, R., Kanwal, S., \& Khan, S. S. (2020). Preferences of the Teachers in Employing Revised Blooms Taxonomy in their Instructions. Sir Syed Journal of Education \& Social Research, 3(2), 258-266. Doi: $139-$

Article Text-1546-2-10- 20200702.pdf

Gul, R., Khan, S. S., \& Akhtar, S. (2020). Organizational Politics as Antecedent of Stress in Public Sector Universities of Khyber Pakhtunkhwa. International Review of Management and Business Research, 9(2), 150-161. Doi:10.30543/9-2(2020)-1I

Gul, R., \& Rafique, M. (2017). Teachers Preferred Approaches towards Multiple Intelligence Teaching: Enhanced Prospects for Teaching Strategies. Journal of Research \& Reflections in Education (JRRE), 11(2). pp 197-203. Available at 3 http://www.ue.edu.pk/jrre

Gul, R., \& Reba, A. (2017). A Study of Multiple Intelligence and Social Profiles of Secondary School Teachers, Peshawar. Journal of Applied Environmental and Biological Sciences, 7(6), 226-235.

Gul, R. (2015). The Effectiveness Of Gardner's Multiple Intelligence Theory On Teaching Strategies Of Secondary School Teachers Peshawar, Pakistan. (PhD Dissertation), Univeristy Of Peshawar, Higher Education Commision, Pakistan. Available from prr.hec.gov.pk

Holmes, A. B. (2013). Effects of manipulatives use on PK-12 mathematics achievement: A meta-analysis. Poster presented at the meeting of Society for Research in Educational Effectiveness, Washington, DC.

Kefee, J. W., (1997). Learning style theory and practice. National association of secondary school principals. Reston, ISBN: o-882-201-X, pp: 25.

Khairnar, C. M., (2015). Advance Pedagogy: Innovative methods of Teaching and learning. International Journal of Information and Education Technology. Vol. 5, No. 11.

Kontaş, H. (2016). The effect of manipulatives on mathematics achievement an attitudes of secondary school students. Journal of education and learning. Vol. 5, No. 3. ISSN 1923-5250.

Laski, E., Jordan, J., Daou, c., \& Murray, A. (2015). What makes mathematics manipulatives effective? Lessons from cognitive science and Montessori education. SAGE Open, 1-8.

Laedbeater, C. \& Wong, A., (2010). Learning from the extremes: A white paper. San jose, Calif., Cisco Systems Inc.

Mensah, J. K., Okyere, M. \& Kuranchie, A. (2013). Student attitude towards mathematics and performance: Does the teacher attitude matter? Journal of education and Practice. Vol. 4, No. 3. ISSN 2222-1735 (paper).

National research council, (2012). Education for life and work developing transferable knowledge and skills in $21^{\text {st }}$ Century. Washington DC, National Academies Press.

Piaget, J. (1965). The child's conception of number. New York: W. W. Norton \& Company.

Scott, L. C., (2015). The futures of learning 3: What kind of pedagogies for the $21^{\text {st }}$ century? Education research and foresight (working papers).

Sessoms, D. (2008). Interactive instruction: Creating Interactive learning environments through tomorrow's teachers. International Journal of Technology in Teaching and learning. 4(2). 86-96.

UNESCO-IBE. (2013). Statement on learning in the post-2015 education and development agenda. Geneva UNESCO, international bureau of education. 
Warwick, J. (2008). Mathematical self-efficacy and student engagement in the mathematics classroom. MSOR Connections. Vol, 8 No. 3, August-October 2008.

Yara, P. O. (2009). Relationship between teachers' attitude and students' academic achievement in mathematics in some selected senior secondary Schools in South- western Nigeria. European Journal of Social Sciences, 11(3), 364-369.

Yasoda, R. (2009). Problems in Teaching and learning Mathematics. Discovery publishing house. New Delhi.

Yilmaz, C., Altun, A. S. \& Olkun, S. (2010). Factors affecting students' attitude 